\title{
A comparative study of the absorption of calcium and the availability of phytate-phosphorus in the golden hamster (Mesocricetus auratus) and the laboratory rat
}

\author{
BY T. G. TAYLOR AND J. W. COLEMAN \\ Department of Nutrition, School of Biochemical and Physiological Sciences, \\ University of Southampton, Southampton $\mathrm{SO}_{9}{ }_{5} \mathrm{NH}$
}

(Received 23 October 1978 - Accepted 19 December 1978)

\begin{abstract}
I. Balance studies were carried out with rats and golden hamsters (Mesocricetus auratus) given diets high and low in calcium ( 10.8 and $5 . \mathrm{I}-5.2 \mathrm{~g} \mathrm{Ca} / \mathrm{kg}$ respectively) and high and low in phytate $(3.4$ and $\mathrm{I} \cdot 6 \mathrm{~g}$ phytatephosphorus $/ \mathrm{kg}$ respectively) in a $2 \times 2$ factorial experiment.

2. Values for $\mathrm{Ca}$ absorption and phytate availability (relative to the amount ingested) and for urinary excretion of $\mathrm{Ca}$ and $\mathrm{P}$ were significantly higher in the hamster than in the rat for all four diets.

3. Phytate availability was significantly greater on the low-Ca than on the high-Ca diets with both species.

4. $\mathrm{Ca}$ absorption was greater on the low-phytate than on the high-phytate diets but the differences were significant only for the hamster.

5. Absorption of both $\mathrm{Ca}$ and $\mathrm{P}$ was poorly controlled in the hamster compared to the rat.
\end{abstract}

Golden hamsters (Mesocricetus auratus) have an unusual ability to absorb calcium from dietary calcium oxalate (Shirley \& Schmidt-Nielsen, 1967) and we were interested in determining whether this animal is also capable of absorbing $\mathrm{Ca}$ with a greater efficiency than other mammals from diets containing high concentrations of phytate.

The availability of $\mathrm{Ca}$ from phytate-containing diets is closely linked to the availability of phytate-phosphorus itself (for review see Taylor, 1965) and in the experiments now reported the ability of rats and hamsters to absorb $\mathrm{Ca}$ and $\mathrm{P}$ from diets varying in their content of $\mathrm{Ca}$ and phytate was compared. The experiment was of a factorial design with two levels of $\mathrm{Ca}$ and two of phytate (high and low levels of each).

\section{EXPERIMENTAL}

Diets. The composition of the four experimental diets is shown in Table I. These diets differed only in their contents of $\mathrm{Ca}$, phytate (supplied mainly as wheat bran) and starch and they were given in the form of pellets. The high-Ca diets contained approximately $10.8 \mathrm{~g} \mathrm{Ca} / \mathrm{kg}$ and the low-Ca diets, which were only marginally low in relation to the estimated requirements of growing rodents, contained $5 \cdot 1-5 \cdot 2 \mathrm{~g} \mathrm{Ca} / \mathrm{kg}$. The $150 \mathrm{~g}$ soya-bean isolate $/ \mathrm{kg}$ diet provided approximately the same amount of phytate as $\mathrm{I} 00 \mathrm{~g}$ bran so that the high-phytate diet (containing $300 \mathrm{~g}$ bran $/ \mathrm{kg}$ ) contained approximately twice as much phytate as the low-phytate diet (containing $100 \mathrm{~g}$ bran $/ \mathrm{kg}$ ). The diets contained $2 \mathrm{~g}$ chromic oxide $/ \mathrm{kg}$ for use as a marker but complete collection of faeces was achieved and samples were not analysed for chromium.

Animals and their treatment. Eight male Wistar rats and eight male golden hamsters, each animal weighing $70-80 \mathrm{~g}$ at the start of the experiment, were used in this study. They were housed singly in metabolism cages and given free access to distilled water. Pairs of animals were fed each diet in turn for a period of 2 weeks according to a Latin square design, so that, during any one period, all four diets were included and over the entire 8-week period each pair received all four diets sequentially. In this way the effects on the experimental results of differences due to age were minimized. 
Table 1. Composition of experimental diets $(\mathrm{g} / \mathrm{kg})$

Phytate status $\ldots$
Calcium status
Diet no.
Soya-bean isolate $(\mathrm{Pr}$
Starch
Wheat bran
Sucrose
Maize oil
Dried yeast
Methionine
$\mathrm{CaCO}_{3}$
$\mathrm{NaCl}^{\mathrm{ZnO}}$
$\mathrm{ZnO}^{\mathrm{MnCO}}{ }_{3}$
$\mathrm{Cr} \mathrm{O}_{3}$
$\mathrm{Retinol}_{(}(\mu \mathrm{g}) \dagger$
Cholecalciferol $(\mu \mathrm{g}) \dagger$
$\mathrm{Ca} \ddagger$
Total phosphorus $\ddagger$
Phytate-P $\ddagger$
Non-phytate-P

$\begin{array}{cc}\begin{array}{c}\text { High } \\ \text { I }\end{array} & \begin{array}{c}\text { Low } \\ 150\end{array} \\ 150 \\ 517 & 532 \\ 100 & 100 \\ 100 & 100 \\ 50 & 50 \\ 50 & 50 \\ 1 & 1 \\ 25 & 10 \\ 5 & 5 \\ 0.12 & 0.12 \\ 0.15 & 0.15 \\ 2 & 2 \\ 600 & 600 \\ 10 & 10 \\ 10.82 & 5.19 \\ 3.05 & 3.14 \\ 1.61 & 1.58 \\ 1.44 & 1.56\end{array}$

$\begin{array}{cc}\text { High } & \text { Low } \\ 3 & 4 \\ 150 & 150 \\ 317 & 332 \\ 300 & 300 \\ 100 & 100 \\ 50 & 50 \\ 50 & 50 \\ \text { I } & 1 \\ 25 & 10 \\ 5 & 5 \\ 0.12 & 0.12 \\ 0.15 & 0.15 \\ 2 & 2 \\ 600 & 600 \\ 10 & 10 \\ 10.84 & 5.06 \\ 5.42 & 5.47 \\ 3.39 & 3.38 \\ 2.03 & 2.09\end{array}$

$\dagger$ As Rovimix (Roche Products Limited).

$\$$ Experimentally determined.

A $4 \mathrm{~d}$ balance study was carried out at the end of each $\mathrm{I} 4 \mathrm{~d}$ experimental period, during which food intake was measured and faeces and urine collected on filter paper (Whatman no. 44, ashless) placed under the wire floor of the cage.

Faeces were separated daily and dried overnight at $100^{\circ}$ before weighing. The bulked samples were ground in a laboratory mill, air-dried and then stored at - $10^{\circ}$ while awaiting analysis.

Urine was extracted by cutting the filter papers into small pieces and shaking them with I $\mathrm{M}$-hydrochloric acid $(50 \mathrm{ml})$ for $3 \mathrm{~h}$. The cages were rinsed, first with $\mathrm{I} \mathrm{M}-\mathrm{HCl}$ and then with distilled water at the end of each period and the washings added to the filter paper extract before making them up to volume.

Analytical methods. Phytate was extracted from ground samples $(200-500 \mathrm{mg})$ of food and faeces by shaking with $0.5 \mathrm{M}-\mathrm{HCl}(25 \mathrm{ml})$ for $3 \mathrm{~h}$ to give a phytate-P concentration of I-2 mmol/1. Triplicate $5 \mathrm{ml}$ portions of the extracts were analysed for phytate by the method of Oshima et al. (1964). Samples of food and faeces (200 $\mathrm{mg}$ ) were placed in hardglass test-tubes and wet digested by heating, first with nitric acid and then with perchloric acid, in an electrically heated block. Distilled water was added to the digests after they had cleared and the solutions were boiled to hydrolyse any pyrophosphate that might have formed to orthophosphate. The solutions were then made up to volume and analysed for $\mathrm{Ca}$ and $\mathrm{P}$, the former by atomic absorption spectrophotometry and the latter by the method of Fiske \& Subbarow (I925).

\section{RESULTS}

The results were analysed by analysis of variance: there were no significant differences between animals or between periods but significant differences between treatments and between species emerged. 
The following terminology was used:

$$
\begin{aligned}
& \text { 'apparent absorption' of } \mathrm{Ca} \text { and } \mathrm{P} \text { and 'availability' of phytate = dietary } \\
& \text { intake - faecal excretion } \\
& \text { relative absorption (or availability) }=\frac{\text { dietary intake }- \text { faecal excretion }}{\text { dietary intake }} \\
& \text { relative urinary excretion }=\frac{\text { urinary excretion }}{\text { dietary intake }} \\
& \text { balance of } \mathrm{Ca} \text { and } \mathrm{P}=\text { dietary intake - faecal excretion - urinary excretion. }
\end{aligned}
$$

Weights of minerals were expressed per $\mathrm{kg}$ body-weight rather than as absolute values to enable inter-species comparisons to be made more readily.

The experimentally determined values for the $\mathrm{Ca}, \mathrm{P}$ and phytate contents of the diets are given in Table 1 and the results of the balance studies in Table 2.

Food intake and growth rate. There were no significant differences between treatments in food intake or in the rate of live-weight gain.

Ca absorption. The apparent absorption of $\mathrm{Ca} / \mathrm{kg}$ body-weight was significantly higher with the high-Ca than with the low-Ca diet for both species. Increasing dietary phytate decreased $\mathrm{Ca}$ absorption but the comparison high $v$. low phytate was significant only for the hamsters. Rats absorbed a smaller proportion of dietary $\mathrm{Ca}$ from the high-Ca than from the low-Ca diets and differences due to phytate concentration were non-significant. Hamsters absorbed $\mathrm{Ca}$ significantly more efficiently than rats with all four diets, and with the lowphytate diets the relative absorption values were greater than $0 \cdot 8$. Relative absorption was significantly depressed by increasing dietary phytate in the hamster but differences due to $\mathrm{Ca}$ level were non-significant, i.e. the hamsters absorbed a similar proportion of $\mathrm{Ca}$ from both high- and low-Ca diets. However, the $\mathrm{Ca} v$. phytate interaction was significant $(P<$ 0.05 ) reflecting the fact that, with the low-phytate diets relative $\mathrm{Ca}$ absorption increased whereas with the high-phytate diets relative absorption decreased when the concentration of dietary $\mathrm{Ca}$ was reduced. The comparison, rat $v$. hamster was non-significant for the actual weights of $\mathrm{Ca}$ absorbed $/ \mathrm{kg}$ body-weight.

Urinary excretion of $\mathrm{Ca}$. Hamsters excreted significantly more $\mathrm{Ca}$ in the urine than rats whether the values were expressed per $\mathrm{kg}$ body-weight or relative to ingested $\mathrm{Ca}$. With the low phytate diets the relative urinary $\mathrm{Ca}$ value was $>0.6$ in the hamster whereas with the rat the highest mean value was $0 . \mathrm{I}$. In both species significantly more $\mathrm{Ca} / \mathrm{kg}$ body-weight was excreted on the high-Ca diet than on the low-Ca diet and increasing dietary phytate reduced $\mathrm{Ca}$ excretion, although the difference was significant only in the rat. However, when urinary $\mathrm{Ca}$ was expressed relative to ingested $\mathrm{Ca}$ increasing the phytate depressed the value in both species to a significant extent. These values were influenced by dietary $\mathrm{Ca}$ only in the rat.

$\mathrm{Ca}$ balance. With the rats, there were no significant differences in $\mathrm{Ca}$ balance due to treatment but the hamsters showed a significantly lower $\mathrm{Ca}$ balance with the low-Ca than with the high-Ca diets. Dietary phytate concentration had no significant effect, however. The balances were significantly greater in the rats than in the hamsters.

$P$ absorption. With both species apparent absorption of $\mathrm{P}$ was significantly higher on the low-Ca than on the high-Ca diets, whether expressed per $\mathrm{kg}$ body-weight or relative to $\mathrm{P}$ intake and more $\mathrm{P}$ per $\mathrm{kg}$ body-weight was absorbed from the high-phytate than from the low-phytate diets. The proportion of dietary $\mathbf{P}$ absorbed by the hamsters was very similar at both phytate levels but the rats absorbed proportionately more $\mathbf{P}$ from the low-phytate 

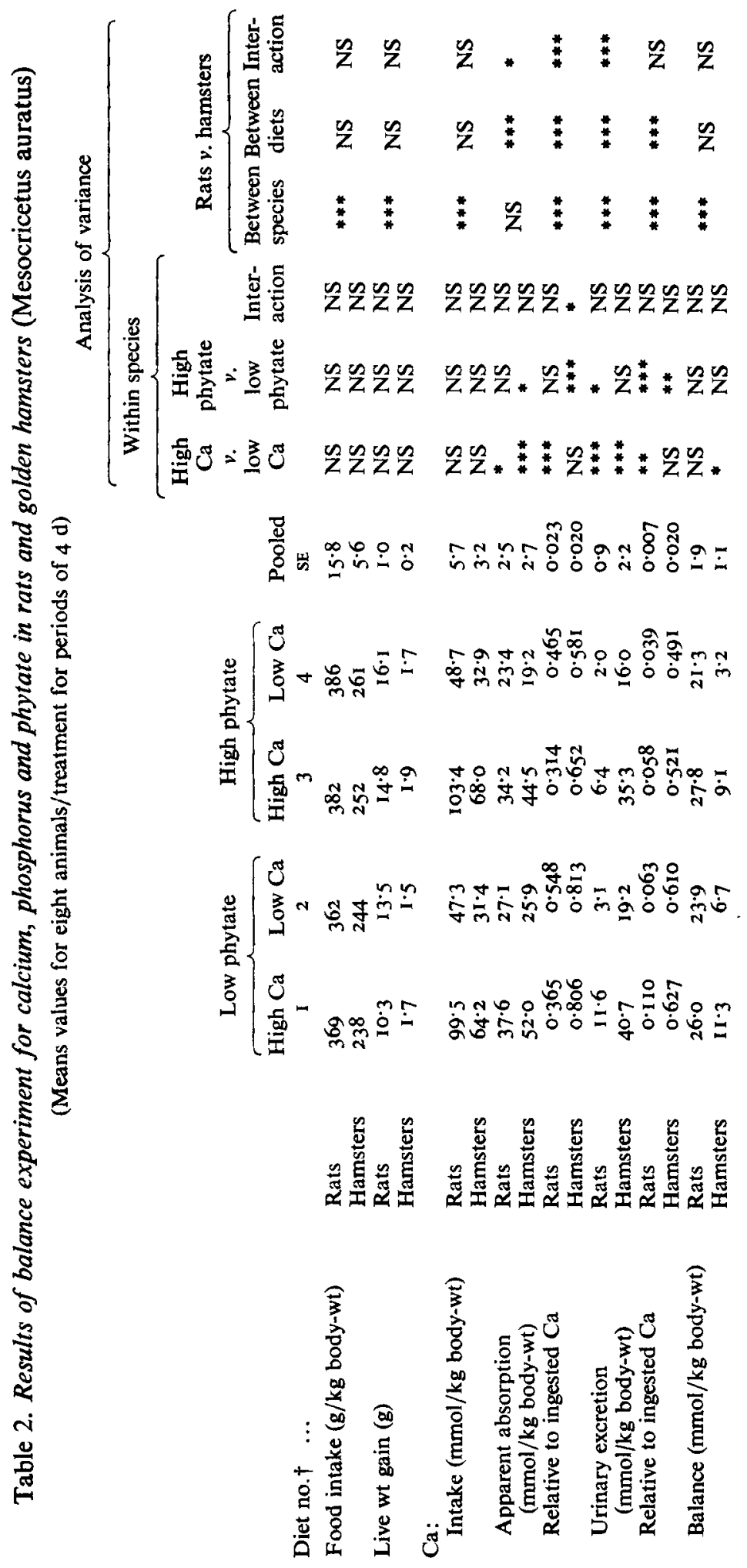


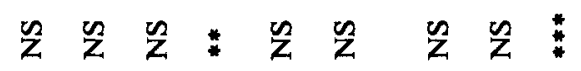

z

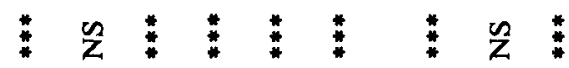

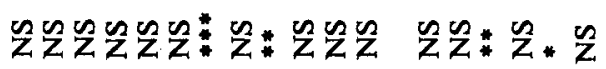

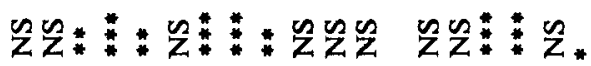

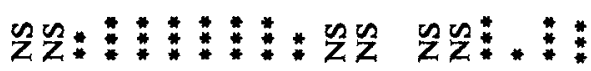

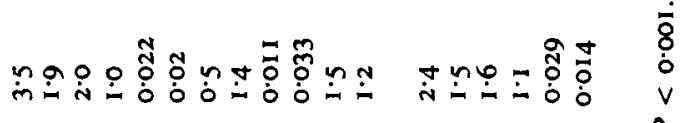

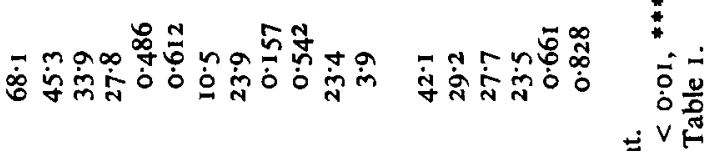

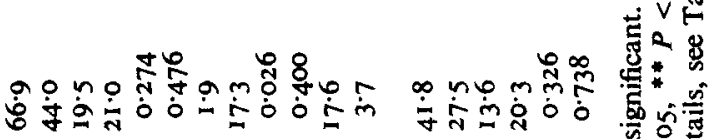
要完

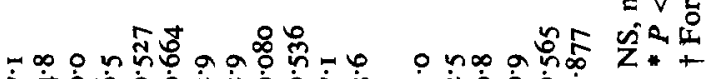

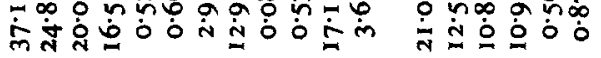

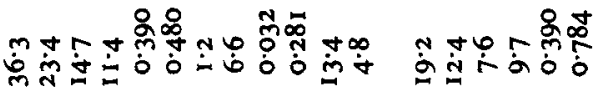

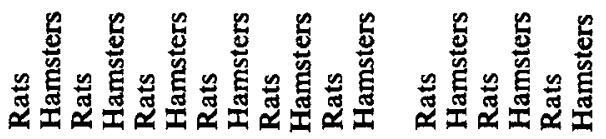

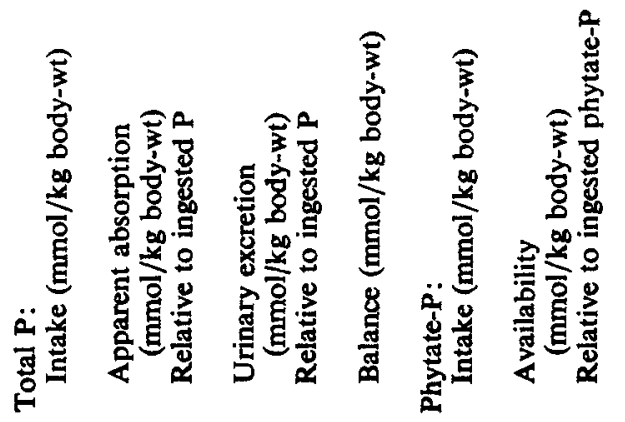


than from the high-phytate diets. There was no difference between species in the apparent absorption of $\mathrm{P} / \mathrm{kg}$ body-weight.

Urinary excretion of $P$. The hamsters excreted significantly more $\mathrm{P}$ in the urine than the rats, both in terms of body-weight and as a proportion of ingested total $\mathrm{P}$. The $\mathrm{Ca} v$. phytate interaction was highly significant in the rat and was related to the very large difference between the high-Ca and low-Ca treatments with the high-phytate compared with the lowphytate diets. Differences in the weight of $\mathbf{P}$ excreted closely reflected differences in $\mathbf{P}$ absorption. In the rats, it was only with the low-Ca-high-phytate diet that the relative urinary excretion value exceeded 0.1 : the corresponding value for the hamsters was 0.54 .

$P$ balance. There were no significant differences between treatments in either species but the balances were significantly higher in the rats, reflecting their greater rate of growth.

Phytate availability. The availability of phytate, i.e. the amount hydrolysed in the gut, was significantly increased as the dietary level of phytate increased and as the level of $\mathrm{Ca}$ decreased in both species, between which there was no significant difference. When availability was expressed relative to dietary intake, differences due to phytate level were nonsignificant in the rat but significant at $P<0.05$ in the hamster, availability being slightly greater with the low-phytate diets. For all diets relative availability values were greater for the hamster than for the rat reaching a maximum of 0.88 for the low-Ca-low-phytate diet and even with the high-Ca-high-phytate diet the value was 0.74 , more than twice the value observed in the rats $(0.33)$. The significant $\mathrm{Ca} v$. phytate interactions for absolute and relative availabilities of phytate-P in the rat reflect the fact that with the high-phytate diets the differences between the high-Ca and low-Ca diets were very large compared with the differences observed with the low-phytate diets.

\section{DISCUSSION}

In these experiments there were no treatments in which the proportion of phytate $P$ varied while total $P$ remained constant, since phytate was added as bran which also provided non-phytate P. It could be argued, therefore, that some of the effects may have been given by differences in total $\mathbf{P}$ rather than by phytate $\mathbf{P}$ alone and this possibility must be recognized. However, compared to the low-phytate diets the high-phytate diets contained approximately twice as much phytate-P but only one-third more non-phytate-P and it seems more probable, therefore, that the effects observed were predominantly due to differences in phytate-P rather than to total $P$.

The diets used in these experiments were designed to be within the normal range for their contents of $\mathrm{Ca}, \mathrm{P}$ and phytate and the absence of significant treatment differences in food intake, live-weight gain and in $P$ balance would tend to confirm the success of this design. However, the results of the $\mathrm{Ca}$ balances suggest that the low-Ca diets may have been marginally deficient for the hamsters.

The rats adapted to the low-Ca diets by absorbing an increased proportion of $\mathrm{Ca}$ but no such adaptation was seen in the hamsters, which absorbed similar proportions from highand low-Ca diets at both levels of dietary phytate. Differences between species in the absorption of $P$ were less great but again the hamsters absorbed a greater proportion of the dietary total $\mathbf{P}$, suggesting that $\mathbf{P}$ absorption too was less well controlled than in the rat. The efficiency of absorption of $\mathrm{Ca}$ and $\mathrm{P}$ by the hamster and its apparent lack of control in relation to requirements was reflected in the high urinary excretion of these minerals in this species.

In both species, $\mathrm{Ca}$ absorption was impaired by increasing the dietary concentration of phytate and phytate hydrolysis was reduced by increasing the dietary concentration of $\mathrm{Ca}$. 
These effects illustrate the classical interactions between $\mathrm{Ca}$ and phytate and they were more marked in the rat than in the hamster. The traditional explanation for these interactions is that $\mathrm{Ca}$ forms a highly insoluble phytate and that phytase (EC 3 . I . 3.8) acts only on soluble phytates, so that, when the ratio phytate: $\mathrm{Ca}$ is increased, an increasing proportion of the $\mathrm{Ca}$ is rendered unavailable for absorption while an increasing proportion of phytate becomes soluble and accessible, therefore, to the action of phytase. Vitamin D increases the availability of phytate-P (Krieger \& Steenbock, 1940) and reduces the rachitogenicity of phytate when low-Ca diets are given (Mellanby, 1950), either by increasing the solubility of phytate (by increasing $\mathrm{Ca}$ absorption thereby reducing the concentration of $\mathrm{Ca}$ in the gut) or by stimulating the production of intestinal phytase (Pileggi et al. 1955). Intestinal phytase is now considered to be identical to one or more of the iso-enzymes of alkaline phosphatase (EC 3. I.3.I) (Pileggi, I959; Davies \& Flett, I978). It seems likely that the effects of increasing the ratio phytate: $\mathrm{Ca}$ on $\mathrm{Ca}$ absorption and on phytate hydrolysis could be mediated ultimately by influencing the metabolism of vitamin $\mathrm{D}$ in the following manner, where $\uparrow$ represents an increase and $\downarrow$ a decrease:

phytate: $\mathrm{Ca} \uparrow \rightarrow$ intestinal solubility of $\mathrm{Ca} \downarrow \rightarrow$ absorption of $\mathrm{Ca} \downarrow \rightarrow$ plasma

$\mathrm{Ca}^{2+} \downarrow \rightarrow$ parathyroid hormone secretion $\uparrow \rightarrow$ kidney 25 -hydroxycholecalciferol-

I-hydroxylase $\uparrow \rightarrow \mathrm{I}, 25$-dihydroxycholecalciferol production $\uparrow \rightarrow \mathrm{Ca}$

absorption and intestinal phytase $\uparrow$.

Whether or not increased production of 1,25-dihydroxycholecalciferol is able to fully compensate for the reduced solubility of $\mathrm{Ca}$ in the gut will depend on the absolute concentration of $\mathrm{Ca}$ and phytate as well as on the ratio between the two.

These experiments do not throw any light on the mechanisms responsible for the efficiency of absorption of $\mathrm{Ca}$ and $\mathrm{P}$ and the efficiency of hydrolysis of phytate in the hamster but they suggest that a detailed study of the absorption of these minerals in vitamin D-deficient and control hamsters would be rewarding. Their ability to absorb large amounts of $\mathrm{Ca}$ from diets rich in phytate is less remarkable than their ability to absorb $\mathrm{Ca}$ from calcium oxalate (Shirley \& Schmidt-Nielsen, 1967) and the former feat could be explained largely in terms of their efficiency in hydrolysing phytate. Whether this is brought about by intestinal or by bacterial phytase remains to be answered.

The authors would like to thank Messrs Roche Products Limited, Dunstable, Beds, for their generous gifts of Rovimix.

\section{REFERENCES}

Davies, N. T. \& Flett, A. A. (1978). Br. J. Nutr. 39, 307.

Fiske, C. H. \& Subbarow, Y. (1925). J. biol. Chem. 66, 375.

Krieger, C. H. \& Steenbock, H. (I940). J. Nutr. 20, I 25.

Mellanby, E. (1950). A Story of Nutritional Research. Baltimore: Williams \& Wilkins.

Oshima, M., Taylor, T. G. \& Williams, A. (1964). Biochem J. 92, 42.

Pileggi, V. J. (1959). Archs Biochem. Biophys. 80, I.

Pileggi, V. J., De Luca, H. F. \& Steenbock, H. (1955). Archs Biochem. Biophys. 58, I94.

Shirley, E. K. \& Schmidt-Nielsen, K. (1967). J. Nutr. 91, 496.

Taylor, T. G. (1965). Proc. Nutr. Soc. 24, 105. 